\title{
ENVIRONMENTAL EVALUATION OF BUILDING MATERIALS - EXAMPLE OF TWO RESIDENTIAL BUILDINGS IN BELGRADE
}

\author{
$U D C 691.3: 504.75: 728.2(045)=111$
}

\section{Ana Radivojević, Miloš Nedić}

\author{
University of Belgrade, Faculty of Architecture, Serbia
}

\begin{abstract}
Environmental friendliness of building materials becomes an important factor in contemporary design and building concept and prerequisite for creation of sustainable buildings, e.g. sustainable architecture. Since in our circumstances, this concept is still at its very beginning, it would be interesting to determine what the answer that our building practice has offered so far has been. Therefore, typical buildings from Belgrade were chosen as models on which evaluation of environmental properties was conducted by using already developed evaluation methods and tools. Results of this research are presented in this work.
\end{abstract}

Key words: building materials, environmental impact, environmental profile.

\section{INTRODUCTION}

In the time when the world economy exerts great efforts to achieve sustainable development on a state or regional level, which includes the building sector and industry, there is an increasing need in our building practice to determine relevant state in the domain of sustainable and environmental correctness of applied building materials and products. Almost a half of the total world energy investments are oriented towards a building sector, and the largest part of these activities is related with production and processing of raw materials and of building materials and products. A number of negative predicted and unpredicted environmental effects, some of which could be equalled to a disaster, are to a great extent caused both by different technological processes and building systems. Therefore, the choice of building materials represents a sensitive process that can have many negative consequences and effects on direct users, but also on the complete environment.

By analyzing building materials that are installed in typical residential buildings in Belgrade, this paper deals with recognition of relevant characteristics of building materials from the ecological point of view, determination of their environmental profile and registering of their potential environmental effects. The main goal of this research was to collect data about environmental profile of building materials and products applied in our

Received February 28, 2008 
building practice, in order to specify the status and position of the building practice in our country within the developed system of environmentally conscious construction in the European Union.

\section{RESEARCH CONTEXT}

It has been more than 30 years since the first UN conference on environment was held in 1972 in Stockholm when the directives regarding a concept of sustainable development were set. Still, there are many questions open, such as capacity and sustainability of resources, protection of bio diversity, acceleration of climate changes, reduction of the total energy consumption, transfer to new technologies and alternative energy sources, minimization of negative environmental impacts, possibilities for realization of an ecological city concept, etc.

There are many currently running projects sponsored by the United Nations, European Union and governments of certain countries that deal with sustainable development problems, questions of environmental friendliness of buildings and assessment of an impact that building industry has on natural and built environment. Having in mind that architectural and civil engineering activities are leaders in distribution and consumption of total world energy capacities, and that the most of this energy comes from exploitation and building materials production processes, the need arose for more serious examination regarding the choice of materials that was done in our building practice, but from the point of view of ecology. In this way, a preliminary review of ecological characteristics of existing buildings can be distinguished and future trends of building construction in a local market can be established.

\section{RESEARCH MODEL}

Construction of residential buildings was a prevalent building activity in Belgrade, first in the period after the World War II that was followed with a mass renovation and construction which lasted till the late 1980's, but also during the last ten years when, in changed market conditions, there was again an expansion of this building type. In the first period, starting from 1960 's, the increasing need for dwellings was solved by the use of various prefabricated building systems. As an illustration, this was the time when New Belgrade was established, where, till 1985, more than 50 residential blocks were constructed, using different industrial, prefabricated construction systems.

Socio-political and economical changes in the region, in the 1990-2000 period resulted in a diminished intensity of construction and stagnation of all the activities concerning the building sector. The circumstances change on the market after the year 2000 led to the changes in building site organization. This is the time of construction of individual residential buildings that varied and differed depending on their urban context and type of financing. Therefore, mass prefabricated systems that had dominated till then had been abandoned and replaced with combined, improved traditional construction system.

Having in mind this situation, two residential buildings were chosen as a research model, representing the typical examples of the mentioned periods regarding applied 
construction principles and systems, as well as materials and products that were used (Figure1). Buildings that were chosen as referent models for the research are:

1. Building A - 5 floor residential building from New Belgrade, Block 64, Gandijeva street No 29, which was built in the late 1980's as a part of one of the last city blocks realized in prefabricated construction system, and

2. Building B - 4 floor + attic residential building in an urban block of Belgrade, Dubljanska street No 10-12, built after year 2000.
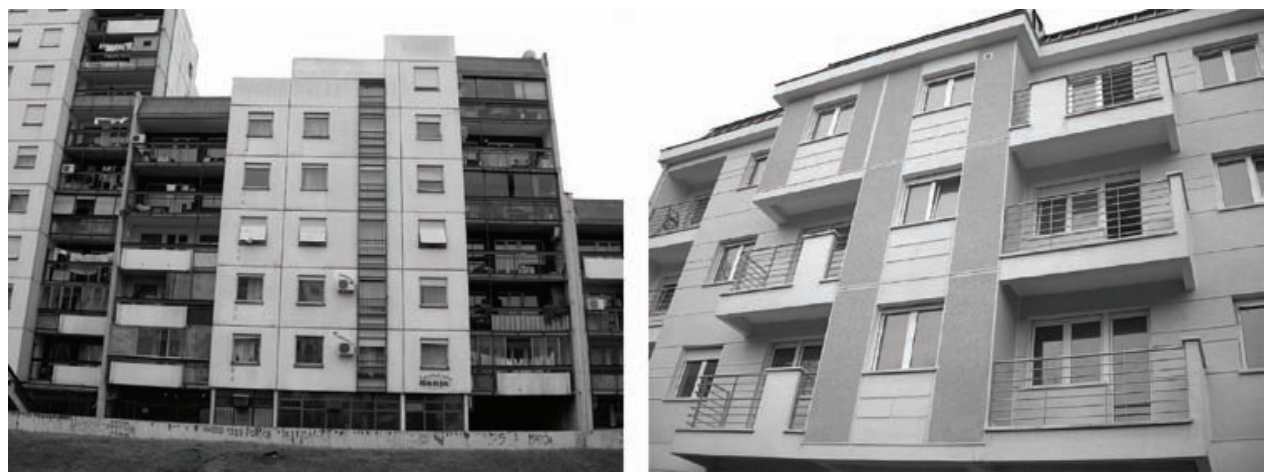

Fig. 1. Model buildings: building A (left), and building B (right)

Being representative for the typical periods of construction, model buildings show significant differences regarding the applied design process, structural characteristics, materials and products that were used, as well as building technology and site organization (Table 1). Therefore, by adequate comparison and evaluation of relevant characteristics of applied building materials and products, it is realistic to expect data that would enable initial evaluation of ecological characteristics of typical buildings of Serbian building practice.

Table 1. Basic characteristics of model buildings

\begin{tabular}{|c|c|c|}
\hline & Building A & Building B \\
\hline Location & Block 64, New Belgrade & Dubljanska street, Vračar, Belgrade \\
\hline type of building & residential & residential \\
\hline date of erection & late 1980 's & after 2000 \\
\hline plot organization & $\begin{array}{l}\text { row of buildings - } \\
\text { between two buildings }\end{array}$ & $\begin{array}{l}\text { row of buildings - } \\
\text { between two buildings }\end{array}$ \\
\hline floor area & $360 \mathrm{~m}^{2}$ & $225 \mathrm{~m}^{2}$ \\
\hline height of building & ground floor +5 & ground floor $+4+$ attic \\
\hline building technology & industrialized, prefabricated & improved, traditional \\
\hline structural system & $\begin{array}{l}\text { prefabricated, large panel, } \\
\text { reinforced concrete system }\end{array}$ & $\begin{array}{l}\text { monolith - in situ, skeleton, } \\
\text { reinforced concrete system }\end{array}$ \\
\hline partitions & prefabricated & built in-situ \\
\hline
\end{tabular}




\section{METHODS FOR RECOGNITION AND EVALUATION OF ECOLOGICAL PROPERTIES}

Understanding the complexity of the problem of recognition and evaluation of ecological characteristics of building materials requires due attention for different aspects from which this problem could be analyzed. According to this, it is necessary to take into account the status and resource capacity of an environment, different environmental effects of materials, energy consumption, life cycle assessment of materials and buildings, etc. It is also necessary to recognize and classify possible types of impacts under which the ecological characteristics of materials could be exhibited in their interaction with environment.

The term ecological properties of building materials concerns different impacts that occur in interaction between built environment - building material - user - surroundings and which directly or indirectly influence the quality of environment by changing it. Types of impacts that could be classified concern: state and exhaustion of resources, pollution of eco-system, health impact on users, energy consumption in different phases of a life cycle of a material, generation and managing of waste materials, potentials for recycling and re-use of materials, and re-starting a new life cycle. Term lyfe cycle of a material or a product becomes a crucial point of interest and considers observation of all successive and connected phases in its life, from extraction of raw material, through the production and application phases till its final deposition.

This indicates a very complex situation regarding possible evaluation and classification of building materials with respect to their ecological or environmental properties. At this moment, one of the transitional solutions for this problem is found in sublimation of several different measures and methods for recognition, testing and evaluation of an environmental profile of a building material. Therefore, it is necessary, in the first place, to define criteria that will help future evaluation of materials. This step will be followed by further systematization and ranking of results depending on the intensity and significance of the expected impact.

In the present-day world practice there are several systems and tools in use designed for recognition of ecological/environmental characteristics of building materials and evaluation of their impact on built and natural environment. Although many of these tools were developed for the needs of local economies, almost all of them are based on the method of a life cycle assessment (LCA), which is additionally worked out and adjusted to local possibilities of evaluation of certain indicators.

Having in mind the mentioned experiences, it was thought that by analyzing individual methods that are used in practice, some of their principles could be used for evaluation that will be conducted in this particular research. Therefore, the following evaluation tools were analyzed: Environmental Preference Method - EPM, Hazardous Building Materials-a guide to selection of environmentally responsible alternatives - HBM, as well as European Union directives and recommendation for design and choice of ecologically friendly products. 


\subsection{Environmental Preference Method - EPM}

The EPM method was developed in the Netherlands in 1991 [1]. It was adjusted to the needs of local economy, offering possibility for practical and simple choice of ecologically friendly building materials and products that were usually used in construction of residential buildings. The approach to the problem of recognition and evaluation of environmental impacts is based on the method of life cycle assessment, but in a more simple way of estimation, based on accessible data and previously obtained data. Unlike LCA method, this one is not focused on the quantitative analyses of certain products, expressed in units like $\mathrm{kg}$ or $\mathrm{m}^{3}$, but it makes wider comparative analysis of optional elements functional units which could be applicable for certain positions in a building.

The principle of this method is to take simultaneously into account different factors, such as various damages of eco system, consumption/exhaustion of resources, energy consumption (in all phases of production, including transport), environmental pollution with different waste and hazardous materials, waste disposal problems, hazardous emissions into the atmosphere, global warming, impact on human beings, re-use and recycling possibilities, etc.

Result of this method is a list of preferable materials and products, made on the basis of evaluation of environmental impacts of each of them, and adjusted to typical positions within a building. This method also takes into account whether it is a matter of construction or refurbishment of a building. Material preference for certain position is made through a four level ranking system which puts materials and products into three priority levels (I, II, III preference), or it excludes them from a final choice. Since this method takes into account all the relevant aspects, it could be considered as a specific combination of global and problem analysis, which easily adapts to the needs of practical implementation. The final product of EPM method is a manual that contains list of preferable materials and products, sorted according to their position in different components of a building and it was already used as a tool for environmental evaluation in some European projects [14].

\subsection{Hazardous Building Materials - a guide to selection of environmentally responsible alternatives - HBM}

This guide was created as a result of a wider project which dealt with impact that building materials have on users and wider environment.[3] The intention of its authors was to create a manual that will serve as an auxiliary tool in a process of material choice, in a way that chosen materials should have the least impact on users' health, have minimal negative impact on environment, but which, at the same time, fulfill other criteria, such as technical, esthetical and financial. Based on experienced knowledge and available information (like in a case of the EPM method), without any additional analyses and tests, the evaluation of building materials and products that are typical for construction of residential buildings is conducted. The factors that were taken into account are the following:

- on a global level - global warming, acidic rains, damages of ozone layer, resource exhaustion, bio-diversity,

- on a local level - soil contamination, generation and management of waste materials, water and air quality, bio-diversity, resource exhaustion, noise, impact of radon, 
- on a health level - sick building syndrome, air quality, water quality, impact of fibrous materials, impact of radon, electro-magnetic radiation, impact of volatile materials.

Like in a case of EPM method, the list of preferable materials and products is created, specified according to their typical position in a building and offering possibility for choosing ecologically friendly materials. Alternative materials and products are ranked considering their technical, health, economical and environmental criteria. The focus of the analysis is shifted to the field of health impact and risk on users and this could be understood, both as uniqueness and special contribution of this method.

HBM method shows certain similarities with EPM method regarding sources and choice of data according to which evaluation of ecological properties is conducted (previous knowledge and available information), while in the process of creation of criteria and indicators for evaluation it relies on the method of life cycle assessment.

\subsection{The European Union - recommendations for sustainable construction}

In the European Union countries, the great efforts are made towards finding methods and procedures for environmental evaluation of building materials. [15] Numerous working groups and committees work to create criteria and indicators for evaluation of ecological impact on environment, with the final goal to form a system of recommendations for designing ecologically acceptable buildings and to create software tools for evaluation of total impact of a building on environment. [16] Some of these recommendations concern:

- reduction of the need for building materials (design rationalization),

- maximization of use of environmentally friendly and healthy materials,

- use of durable materials,

- use of materials from renewable resources,

- maximization of dismantling possibilities of buildings and its components,

- maximization of re-use possibilities of buildings and its components,

- designing with an idea for possible recycling,

- application of recycled materials,

- avoiding application of hazardous substances (PVC, solvents),

- obligation to create a data base of expected effects.

It is obvious that the process of recognition of impacts and evaluation of environmental properties is ambiguous. Therefore at this moment it would be very difficult to set universal ways and evaluation tools which would, in all environments, give satisfactory results according to the mentioned levels. Nevertheless, with sublimation of certain methods and procedures, as well as their modification and extension according to the local needs, it is possible to achieve satisfactory level of environmental evaluation of building materials and products, with possibility to transfer the acquired results to the building level as a desired final product. 


\section{INVENTORING, ANALYSES AND EVALUATION OF DATA}

Due to the relevance of mentioned aspects, offered data systematization and possibilities for practical and simple use (which are of special significance for this particular research), EPM method could be considered as an adequate starting basis for evaluation of research models. Another reason for choosing this method is the fact that in evaluation and ranking process it covers almost all of the defined criteria which are relevant for evaluation of environmental impact. Therefore, EPM method will be used as the primary evaluation method of created model data base. In order to clarify and define possible negative effects and direct impacts on users' health, further testing will be conducted by using HBM method which is specific for taking into consideration health aspects. Finally, after analyzing data with these two methods, they will be commented with respect to the relevant EU criteria and recommendations.

The need for making a comparable and compatible data base which would offer a starting base for a further evaluation of environmental profile of building materials brought about creation of the data base on the model buildings of this research. The obtained data resulted in a data base containing relevant information about all of materials and products that were applied on both of the chosen model buildings. For better understanding and comparison of results, the applied materials and products were sorted regarding their position, e.g. component that they create within a building, such as foundations, structural elements and systems, external and internal partitions, coverings, equipment elements, etc. Sorted in this way, the data were later evaluated according to the following principle.

The first step data analysis was conducted using the EPM evaluation method, as a primary method for determination of ecological profile of materials. Ranking of materials is conducted with the use of a four-step scale: 1-4. Values 1-3 concern materials whose usage is considered acceptable and ranked from the most (value 1) till the least preferential (value 3), while value 4 (not recommended) is given to those materials which create or have certain negative environmental impact, or to those which have an acceptable alternative that could be used at the particular position in a building. Whenever it was possible in this work, preferential material was noted as a possible alternative and better solution from ecological point of view for the particular position in a building.

The second step analysis was conducted using HBM evaluation method, but focused on determination of negative impact that building materials could have on the health of the users. Materials were evaluated and ranked in two possible situations: during their exploitation, but also during dismantling from a position they were built in, when certain negative environmental impacts could occur. Results are expressed as E/D, where first value - E concerns possible impact during exploitation, while, value $\mathrm{D}$ shows impact that material has during its dismantling or demolition. Ranking is made through a scale 0-3, where values 0-2 represent those materials that are acceptable for application in a certain position (value 0 - the most acceptable, value 2 - the least acceptable), while value 3 is given to those materials which are not recommended to be used, or which could be replaced with other, more acceptable alternatives. Like in the case of EPM method, in this analysis as well, alternative materials were recommended, whenever it was possible. The results of these analyses are presented in Table 2. 
Table 2. Evaluation of environmental characteristics of applied building materials and products, used on model buildings A and B with EPM and HBM methods

\begin{tabular}{|c|c|c|c|c|c|}
\hline \multicolumn{3}{|c|}{ BUILDING A } & \multicolumn{3}{|c|}{ BUILDING B } \\
\hline \multirow{3}{*}{ applied material } & \multicolumn{2}{|c|}{ evaluation method } & \multirow{3}{*}{ applied material } & \multicolumn{2}{|c|}{ evaluation method } \\
\hline & EPM & HBM & & EPM & HBM \\
\hline & $\begin{array}{l}\text { recommended } \\
\text { alternative }\end{array}$ & $\begin{array}{l}\text { recommended } \\
\text { alternative }\end{array}$ & & $\begin{array}{l}\text { recommended } \\
\text { alternative }\end{array}$ & $\begin{array}{l}\text { recommended } \\
\text { alternative }\end{array}$ \\
\hline \multicolumn{6}{|c|}{ position in building - FOUNDATIONS } \\
\hline $\begin{array}{l}\text { reinforced } \\
\text { concrete }\end{array}$ & 2 & $0 / 0$ & $\begin{array}{l}\text { reinforced } \\
\text { concrete }\end{array}$ & 2 & $0 / 0$ \\
\hline \multicolumn{6}{|c|}{ position in building - FLOOR ON THE GROUND } \\
\hline \multirow[b]{2}{*}{$\begin{array}{l}\text { reinforced } \\
\text { concrete }\end{array}$} & $\begin{array}{l}4, \mathrm{NOT} \\
\text { recomm. }\end{array}$ & \multirow[b]{2}{*}{$0 / 0$} & \multirow[b]{2}{*}{$\begin{array}{l}\text { reinforced } \\
\text { concrete }\end{array}$} & $\begin{array}{c}4, \text { NOT } \\
\text { recomm. }\end{array}$ & \multirow[b]{2}{*}{$0 / 0$} \\
\hline & $\begin{array}{l}\text { concrete with } \\
\text { reclaimed } \\
\text { aggregate }\end{array}$ & & & $\begin{array}{l}\text { concrete with } \\
\text { reclaimed } \\
\text { aggregate }\end{array}$ & \\
\hline \multirow[b]{2}{*}{ plain concrete } & $\begin{array}{l}4, \text { NOT } \\
\text { recomm. }\end{array}$ & \multirow[b]{2}{*}{$0 / 0$} & \multirow[b]{2}{*}{ lean concrete } & $\begin{array}{l}\text { 4, NOT } \\
\text { recomm. }\end{array}$ & \multirow[b]{2}{*}{$0 / 0$} \\
\hline & $\begin{array}{l}\text { concrete with } \\
\text { reclaimed } \\
\text { aggregate }\end{array}$ & & & $\begin{array}{l}\text { concrete with } \\
\text { reclaimed } \\
\text { aggregate }\end{array}$ & \\
\hline sand & 2 & $0 / 0$ & - & - & - \\
\hline \multirow{2}{*}{ gravel } & $\begin{array}{l}4, \mathrm{NOT} \\
\text { recomm. }\end{array}$ & \multirow{2}{*}{$0 / 0$} & \multirow{2}{*}{-} & \multirow{2}{*}{-} & \multirow{2}{*}{-} \\
\hline & $\begin{array}{l}\text { reclaimed } \\
\text { aggreg. }\end{array}$ & & & & \\
\hline $\begin{array}{l}\text { bituminous } \\
\text { damp } \\
\text { membrane }\end{array}$ & 1 & $0 / 0$ & $\begin{array}{l}\text { bituminous } \\
\text { damp } \\
\text { membrane }\end{array}$ & 1 & $0 / 0$ \\
\hline asphalt & 1 & $0 / 0$ & - & - & - \\
\hline cement screed & - & $0 / 0$ & $\begin{array}{c}\text { reinforced } \\
\text { cement screed }\end{array}$ & - & $0 / 0$ \\
\hline \multirow[b]{2}{*}{ concrete tiles } & NOT recomm. & \multirow[b]{2}{*}{$0 / 0$} & \multirow[b]{2}{*}{-} & \multirow[b]{2}{*}{-} & \multirow[b]{2}{*}{-} \\
\hline & $\begin{array}{l}\text { concrete tiles } \\
\text { with reclaimed } \\
\text { aggregate }\end{array}$ & & & & \\
\hline \multicolumn{6}{|c|}{ position in building - EXTERNAL WALLS BELOW GROUND } \\
\hline \multirow{2}{*}{$\begin{array}{l}\text { reinforced } \\
\text { concrete }\end{array}$} & $\begin{array}{c}4, \mathrm{NOT} \\
\text { recomm. }\end{array}$ & \multirow{2}{*}{$0 / 0$} & \multirow{2}{*}{$\begin{array}{l}\text { reinforced } \\
\text { concrete }\end{array}$} & $\begin{array}{c}4, \mathrm{NOT} \\
\text { recomm. }\end{array}$ & \multirow{2}{*}{$0 / 0$} \\
\hline & $\begin{array}{c}\text { hollow concr. } \\
\text { blocks }\end{array}$ & & & $\begin{array}{c}\text { hollow concr. } \\
\text { Blocks }\end{array}$ & \\
\hline $\begin{array}{c}\text { bitumenous } \\
\text { paint }\end{array}$ & 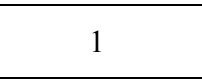 & $0 / 0$ & $\begin{array}{c}\text { bitumenous } \\
\text { paint }\end{array}$ & 1 & $0 / 0$ \\
\hline $\begin{array}{l}\text { bitumenous } \\
\text { paper }\end{array}$ & 1 & $0 / 0$ & cement mortar & - & - \\
\hline $\begin{array}{l}\text { bituminous } \\
\text { damp } \\
\text { membrane }\end{array}$ & 1 & $0 / 0$ & $\begin{array}{l}\text { bituminous } \\
\text { damp } \\
\text { membrane }\end{array}$ & 1 & $0 / 0$ \\
\hline clay bricks & 2 & $0 / 0$ & clay brick & 2 & $0 / 0$ \\
\hline
\end{tabular}


Environmental Evaluation of Building Materials - Example of Two Residential Buildings in Belgrade 105

\begin{tabular}{|c|c|c|c|c|c|}
\hline \multicolumn{3}{|c|}{ BUILDING A } & \multicolumn{3}{|c|}{ BUILDING B } \\
\hline \multirow{3}{*}{ applied material } & \multicolumn{2}{|c|}{\begin{tabular}{|c|} 
evaluation method \\
\end{tabular}} & \multirow{3}{*}{ applied material } & \multicolumn{2}{|c|}{ evaluation method } \\
\hline & EPM & HBM & & EPM & HBM \\
\hline & $\begin{array}{l}\text { recommended } \\
\text { alternative }\end{array}$ & $\begin{array}{c}\text { recommended } \\
\text { alternative }\end{array}$ & & $\begin{array}{l}\text { recommended } \\
\text { alternative }\end{array}$ & $\begin{array}{c}\text { recommended } \\
\text { alternative }\end{array}$ \\
\hline \multicolumn{6}{|c|}{ position in building - EXTERNAL WALLS } \\
\hline $\begin{array}{l}\text { reinforced } \\
\text { concrete }\end{array}$ & $\begin{array}{l}4, \mathrm{NOT} \\
\text { recomm. }\end{array}$ & $0 / 0$ & $\begin{array}{c}\text { reinforced } \\
\text { concrete }\end{array}$ & $\begin{array}{l}\text { 4, NOT } \\
\text { recomm. }\end{array}$ & $0 / 0$ \\
\hline $\begin{array}{l}\text { lightweight } \\
\text { concrete }\end{array}$ & 2 & $0 / 0$ & clay blocks & 1 & $0 / 0$ \\
\hline clay bricks & 2 & $0 / 0$ & clay bricks & 2 & $0 / 0$ \\
\hline EPS insulation & 2 & $0 / 0$ & EPS insulation & 2 & $0 / 0$ \\
\hline aluminum foil & - & $0 / 0$ & $\begin{array}{c}\text { cement-lime } \\
\text { mortar }\end{array}$ & 2 & $0 / 0$ \\
\hline acrylic paint & 3 & $0 / 0$ & $\begin{array}{l}\text { artificial stone } \\
\text { rendering }\end{array}$ & 2 & $0 / 0$ \\
\hline \multicolumn{6}{|c|}{ position in building - INTERNAL WALLS } \\
\hline $\begin{array}{l}\text { reinforced } \\
\text { concrete }\end{array}$ & $\begin{array}{l}\text { 4, NOT } \\
\text { recomm. }\end{array}$ & $0 / 0$ & & & \\
\hline $\begin{array}{l}\text { lightweight } \\
\text { concrete }\end{array}$ & 3 & $0 / 0$ & clay blocks & 2 & $0 / 0$ \\
\hline $\begin{array}{c}\text { gypsum } \\
\text { boards }+ \\
\text { timber frame } \\
\text { construction }\end{array}$ & 1 & $0 / 0$ & clay bricks & 2 & $0 / 0$ \\
\hline ceramic tiles & 1 & $0 / 0$ & ceramic tiles & 1 & $0 / 0$ \\
\hline $\begin{array}{l}\text { vinyl coated } \\
\text { paper }\end{array}$ & - & $0 / 0$ & & & \\
\hline $\begin{array}{l}\text { thermo } \\
\text { insulating } \\
\text { plaster }\end{array}$ & 3 & $0 / 0$ & $\begin{array}{l}\text { cement-lime } \\
\text { plaster }\end{array}$ & 2 & $0 / 0$ \\
\hline mineral paint & 1 & $0 / 0$ & mineral paint & 1 & $0 / 0$ \\
\hline \multicolumn{6}{|c|}{ position in building - FLOOR } \\
\hline \multirow{2}{*}{$\begin{array}{c}\text { reinforced } \\
\text { concrete slab }\end{array}$} & $\begin{array}{c}4, \mathrm{NOT} \\
\text { recomm. }\end{array}$ & \multirow{2}{*}{$0 / 0$} & \multirow{2}{*}{$\begin{array}{c}\text { hollow ceramic } \\
\text { elememts and } \\
\text { concrete } \\
\text { elements }\end{array}$} & \multirow{2}{*}{2} & \multirow{2}{*}{$0 / 0$} \\
\hline & $\begin{array}{c}\text { hollow concrete } \\
\text { floor }\end{array}$ & & & & \\
\hline $\begin{array}{l}\text { thin-layer } \\
\text { plaster }\end{array}$ & - & - & $\begin{array}{l}\text { cement-lime } \\
\text { plaster }\end{array}$ & 2 & $0 / 0$ \\
\hline screed & 3 & $0 / 0$ & screed & 3 & $0 / 0$ \\
\hline mineral wool & 1 & $0 / 0$ & mineral wool & 1 & $0 / 0$ \\
\hline PVC foil & $\begin{array}{l}4, \mathrm{NOT} \\
\text { recomm. }\end{array}$ & $0 / 0$ & PVC foil & $\begin{array}{l}4, \mathrm{NOT} \\
\text { recomm. }\end{array}$ & $0 / 0$ \\
\hline \begin{tabular}{|c|} 
bituminous \\
damp membrane
\end{tabular} & 1 & $0 / 0$ & $\begin{array}{c}\text { bituminous } \\
\text { damp membrane }\end{array}$ & 1 & $0 / 0$ \\
\hline $\begin{array}{c}\text { stripped oak } \\
\text { parquet }\end{array}$ & 2 & $0 / 0$ & parquet & 1 & $0 / 0$ \\
\hline $\begin{array}{c}\text { vinyl-asbestos } \\
\text { tiles }\end{array}$ & $\begin{array}{l}4, \text { NOT } \\
\text { recomm. }\end{array}$ & $1 / 3$ & - & - & - \\
\hline
\end{tabular}




\begin{tabular}{|c|c|c|c|c|c|}
\hline \multicolumn{3}{|c|}{ BUILDING A } & \multicolumn{3}{|c|}{ BUILDING B } \\
\hline \multirow{3}{*}{ applied material } & \multicolumn{2}{|c|}{ evaluation method } & \multirow[b]{3}{*}{ applied material } & \multicolumn{2}{|c|}{ evaluation method } \\
\hline & EPM & HBM & & EPM & HBM \\
\hline & $\begin{array}{c}\text { recommended } \\
\text { alternative }\end{array}$ & $\begin{array}{c}\text { recommended } \\
\text { alternative }\end{array}$ & & $\begin{array}{c}\text { recommended } \\
\text { alternative }\end{array}$ & $\begin{array}{c}\text { recommended } \\
\text { alternative }\end{array}$ \\
\hline \multirow{2}{*}{$\begin{array}{c}\text { phenol- } \\
\text { formaldehyde } \\
\text { boards }\end{array}$} & \begin{tabular}{|l|}
$4, \mathrm{NOT}$ \\
recomm. \\
\end{tabular} & \multirow{2}{*}{$0 / 0$} & \multirow{2}{*}{$\begin{array}{l}\text { cement-bonded } \\
\text { wood-wool }\end{array}$} & \multirow[t]{2}{*}{2} & \multirow[t]{2}{*}{$0 / 0$} \\
\hline & mineral wool & & & & \\
\hline terazzo tiles & 1 & $0 / 0$ & & & \\
\hline ceramic tiles & 2 & $0 / 0$ & ceramic tiles & 2 & $0 / 0$ \\
\hline mineral paint & 1 & $0 / 0$ & mineral paint & 1 & $0 / 0$ \\
\hline $\begin{array}{c}\text { rubber sheet } \\
\text { covering }\end{array}$ & 1 & $0 / 0$ & - & - & - \\
\hline wooden strips & 1 & $0 / 0$ & - & - & - \\
\hline \multirow{2}{*}{$\begin{array}{l}\text { synthetic floor } \\
\text { covering }\end{array}$} & $\begin{array}{l}4, \mathrm{NOT} \\
\text { recomm. }\end{array}$ & \multirow{2}{*}{\begin{tabular}{|c|}
$0 / 0$ \\
wood, \\
ceramics \\
\end{tabular}} & \multirow[t]{2}{*}{-} & \multirow[t]{2}{*}{-} & \multirow[t]{2}{*}{-} \\
\hline & wood, ceramics & & & & \\
\hline \multicolumn{6}{|c|}{ position in building - ROOF STRUCTURE } \\
\hline flat roof & 3 & & pitched roof & 1 & \\
\hline \multirow{2}{*}{$\begin{array}{c}\text { reinforced } \\
\text { concrete slab }\end{array}$} & $\begin{array}{l}\text { 4, NOT } \\
\text { recomm. }\end{array}$ & \multirow{2}{*}{$0 / 0$} & \multirow{2}{*}{$\begin{array}{l}\text { cement-lime } \\
\text { plaster }\end{array}$} & \multirow{2}{*}{2} & \multirow{2}{*}{$0 / 0$} \\
\hline & $\begin{array}{l}\text { lightweight } \\
\text { concrete }\end{array}$ & & & & \\
\hline $\begin{array}{l}\text { lightweight } \\
\text { concrete }\end{array}$ & 2 & $0 / 0$ & $\begin{array}{c}\text { hollow ceramic } \\
\text { elememts and } \\
\text { concrete } \\
\text { elements }\end{array}$ & 2 & $0 / 0$ \\
\hline $\begin{array}{c}\text { aluminum } \\
\text { vapour barrier }\end{array}$ & 2 & $0 / 0$ & $\begin{array}{c}\text { aluminum } \\
\text { vapour barrier }\end{array}$ & 2 & $0 / 0$ \\
\hline \multirow{2}{*}{$\begin{array}{l}\text { polyurethane } \\
\text { insulation }\end{array}$} & $\begin{array}{l}4, \mathrm{NOT} \\
\text { recomm. }\end{array}$ & \multirow{2}{*}{$0 / 0$} & \multirow{2}{*}{ mineral wool } & \multirow{2}{*}{2} & $0 / 2$ \\
\hline & $\begin{array}{l}\text { EPS, mineral } \\
\text { wool }\end{array}$ & & & & $\begin{array}{l}\text { EPS, XPS, } \\
\text { porofen }\end{array}$ \\
\hline $\begin{array}{l}\text { bituminous } \\
\text { damp } \\
\text { membrane }\end{array}$ & 2 & $0 / 0$ & $\begin{array}{c}\text { wooden } \\
\text { substructure }\end{array}$ & 1 & $0 / 0$ \\
\hline sand & 2 & $0 / 0$ & & & \\
\hline gravel & 2 & $0 / 0$ & & & \\
\hline \multirow[t]{2}{*}{ concrete tiles } & \multirow[t]{2}{*}{2} & \multirow[t]{2}{*}{$0 / 0$} & \multirow[t]{2}{*}{ aluminum sheet } & $\begin{array}{l}\text { 4, NOT } \\
\text { recomm. }\end{array}$ & \multirow[t]{2}{*}{$0 / 0$} \\
\hline & & & & ceramic tiles & \\
\hline & position in bu & ilding - EXTEI & RNAL DOORS / & WINDOWS & \\
\hline laminated & 1 & $0 / 0$ & PVC frame & $\begin{array}{l}\text { 4, NOT } \\
\text { recomm. }\end{array}$ & $0 / 0$ \\
\hline wooden trame & & & & wooden frame & \\
\hline $\begin{array}{c}\text { single glazing } \\
\text { in double panel } \\
\text { frame }\end{array}$ & 3 & $0 / 0$ & $\begin{array}{l}\text { thermo } \\
\text { insulating } \\
\text { glazing }\end{array}$ & 1 & $0 / 0$ \\
\hline
\end{tabular}




\begin{tabular}{|c|c|c|c|c|c|}
\hline \multicolumn{3}{|c|}{ BUILDING A } & \multicolumn{3}{|c|}{ BUILDING B } \\
\hline \multirow{3}{*}{ applied material } & \multicolumn{2}{|c|}{ evaluation method } & \multirow{3}{*}{ applied material } & \multicolumn{2}{|c|}{ evaluation method } \\
\hline & EPM & HBM & & EPM & HBM \\
\hline & $\begin{array}{c}\text { recommended } \\
\text { alternative }\end{array}$ & $\begin{array}{c}\text { recommended } \\
\text { alternative }\end{array}$ & & $\begin{array}{c}\text { recommended } \\
\text { alternative }\end{array}$ & $\begin{array}{c}\text { recommended } \\
\text { alternative }\end{array}$ \\
\hline \multirow{2}{*}{$\begin{array}{l}\text { aluminum } \\
\text { frame }\end{array}$} & $\begin{array}{l}4, \mathrm{NOT} \\
\text { recomm. }\end{array}$ & \multirow[t]{2}{*}{$0 / 0$} & \multirow[t]{2}{*}{ PVC frame } & \multirow[t]{2}{*}{1} & \multirow[t]{2}{*}{$0 / 0$} \\
\hline & wooden frame & & & & \\
\hline window sealant & - & $0 / 0$ & silicone sealant & 1 & $0 / 0$ \\
\hline rubber sealant & 1 & $0 / 0$ & rubber sealant & 1 & $0 / 0$ \\
\hline \multirow[t]{2}{*}{ PVC blinds } & $\begin{array}{l}4, \mathrm{NOT} \\
\text { recomm. }\end{array}$ & \multirow[t]{2}{*}{-} & \multirow[t]{2}{*}{ PVC blinds } & $\begin{array}{l}\text { 4, } \mathrm{NOT} \\
\text { recomm. }\end{array}$ & \multirow[t]{2}{*}{-} \\
\hline & wooden blinds & & & wooden blinds & \\
\hline $\begin{array}{c}\text { zinc-steel sheet } \\
\text { window sill }\end{array}$ & 2 & $0 / 0$ & $\begin{array}{c}\text { zinc-steel sheet } \\
\text { window sill }\end{array}$ & 2 & $0 / 0$ \\
\hline \multicolumn{6}{|c|}{ position in building - INTERNAL DOORS } \\
\hline wooden frame & 1 & $0 / 0$ & wooden frame & 1 & $0 / 0$ \\
\hline steel frame & 1 & $0 / 0$ & steel frame & 1 & $0 / 0$ \\
\hline $\begin{array}{c}\text { honeycomb } \\
\text { with hardboard } \\
\text { skins } \\
\end{array}$ & 1 & $0 / 0$ & \begin{tabular}{|c|} 
honeycomb \\
with hardboard \\
skins
\end{tabular} & 1 & $0 / 0$ \\
\hline \multicolumn{6}{|c|}{ position in building - METAL FRAMED WINDOWS, DOORS AND PARTITION WALLS } \\
\hline \multirow[t]{2}{*}{ steel frame } & \multirow[t]{2}{*}{2} & \multirow[t]{2}{*}{$0 / 0$} & \multirow{2}{*}{$\begin{array}{l}\text { anodized } \\
\text { aluminum } \\
\text { frame }\end{array}$} & $\begin{array}{l}\text { 4, NOT } \\
\text { recomm. }\end{array}$ & \multirow[t]{2}{*}{$0 / 0$} \\
\hline & & & & steel frame & \\
\hline \multirow{2}{*}{ single glazing } & $\begin{array}{r}4, \mathrm{NOT} \\
\text { recomm. }\end{array}$ & \multirow{2}{*}{$0 / 0$} & \multirow{2}{*}{ insulating glass } & \multirow{2}{*}{1} & \multirow{2}{*}{$0 / 0$} \\
\hline & $\begin{array}{l}\text { insulating } \\
\text { glazing }\end{array}$ & & & & \\
\hline reinforced glass & 2 & $0 / 0$ & $\begin{array}{c}\text { INOX steel } \\
\text { sheet }\end{array}$ & 1 & $0 / 0$ \\
\hline metal paint & - & - & & & \\
\hline \multicolumn{6}{|c|}{ position in building-RAILINGS... } \\
\hline steel frame & 3 & $0 / 0$ & steel frame & 3 & $0 / 0$ \\
\hline \multirow[t]{2}{*}{-} & \multirow[t]{2}{*}{-} & \multirow[t]{2}{*}{-} & aluminum & $\begin{array}{l}\text { 4, NOT } \\
\text { recomm. }\end{array}$ & $0 / 0$ \\
\hline & & & & steel frame & \\
\hline reinforced & $\begin{array}{l}4, \mathrm{NOT} \\
\text { recomm. }\end{array}$ & $0 / 0$ & clay bricks & 1 & $0 / 0$ \\
\hline & masonry walls & & & & \\
\hline metal paint & - & - & metal paint & - & - \\
\hline acrylic paint & 3 & $0 / 0$ & acrylic paint & 3 & $0 / 0$ \\
\hline
\end{tabular}

\section{INTERPRETATION OF RESULTS}

The review of obtained results shows significant difference among used evaluation methods. In the case of EPM methods, evaluation results show that great number of applied materials and products, in case of both model buildings, partly or completely do not 
fulfill the desired criteria. On the other hand, results of evaluation using HBM method show that almost all of the applied materials, with several exceptions, fulfill the required conditions. This indicates inability to sublimate results of these two methods, or to interpret them uniformly and indicates the need that each of applied methods should be used separately and obtained results should be compared and combined later on.

Conducted evaluation according to the EPM method showed that, in case of both model buildings, certain materials were evaluated as unacceptable from the ecological point of view and due to their environmental impact they were not recommended for use. These materials and reasons for being unacceptable for use are shown in a Table 3.

Table 3. Unacceptable building materials that were used in model buildings A and B

\begin{tabular}{|c|c|}
\hline Unacceptable building material & Negative environmental impact \\
\hline natural gravel & $\begin{array}{l}\text { exhaustion of resources } \\
\text { change of landscape due to excavation of raw material } \\
\text { energy consumption during excavation of raw material }\end{array}$ \\
\hline lean and plain concrete & $\begin{array}{l}\text { energy consumption during cement production } \\
\mathrm{CO}_{2} \text { emission }\end{array}$ \\
\hline reinforced concrete & $\begin{array}{l}\text { pollution during ore extraction and steel production } \\
\text { energy consumption during cement production } \\
\mathrm{CO}_{2} \text { emission }\end{array}$ \\
\hline prefabricated concrete panels & $\begin{array}{l}\text { pollution during ore extraction and steel production } \\
\text { energy consumption during cement production } \\
\mathrm{CO}_{2} \text { emission }\end{array}$ \\
\hline single glazing & $\begin{array}{l}\text { impact on living comfort } \\
\text { great energy consumption for heating and cooling }\end{array}$ \\
\hline $\begin{array}{l}\text { plastic shutters and blinds, } \\
\text { vinyl coated papers }\end{array}$ & content of PVC \\
\hline PVC foils & $\begin{array}{l}\text { environmental impact during production } \\
\text { complicated recycling process }\end{array}$ \\
\hline vinyl - asbestos plates & $\begin{array}{l}\text { content of vinyl and potentially hazardous asbestos fibers } \\
\text { toxic impact on users' health during dismantling } \\
\text { complicated procedure of deposition of asbestos' waste }\end{array}$ \\
\hline $\begin{array}{l}\text { "porofen" - phenol- } \\
\text { formaldehyde boards }\end{array}$ & $\begin{array}{l}\text { content of phenol foams } \\
\text { great internal energy } \\
\text { pollution during production and demolition }\end{array}$ \\
\hline synthetic floor covering & $\begin{array}{l}\text { environmental impact during production } \\
\text { complicate recycling process }\end{array}$ \\
\hline $\begin{array}{l}\text { polyurethane foams and } \\
\text { insulations }\end{array}$ & $\begin{array}{l}\text { impact on ozone envelope during production } \\
\text { impact during demolition }\end{array}$ \\
\hline aluminium profiles and sheets & $\begin{array}{l}\text { great energy consumption during excavation and refining of } \\
\text { raw material }\end{array}$ \\
\hline
\end{tabular}

It was found out that in the case of the building A this kind of building materials were applied twice as much. If there was a need to replace some of the applied materials with alternative ones from the places where they did not fulfill the set criteria, it was more easily achieved in the case of the building B, since the necessary replacements could be conducted without significant effects on the structure or general functioning of the building. 
Evaluation also pointed out that among applied building materials, those that showed the best results from the ecological point of view were: bitumen-based damp membranes and other bitumen-based materials, ceramic, e.g. clay-based products - bricks and blocks, gypsum (gypsum-based partition walls), ceramic products (floor and wall tiles), waterbased paints, mineral wool (thermo insulating boards for floors and walls), terazzo (floor covering), rubber (floor covering), thermo-insulating glazing, silicon (sealants) and steel (profiles and sheets from galvanized and stainless steel).

Presence of these materials is almost equal in cases of both model buildings, although it should be mentioned that apart from ceramic bricks and blocks, all the other materials and products represent coverings or other finishing works in a buildings. Having this in mind, slight advantage could be given to the building B whose structure to a great extent includes ceramic bricks and blocks, unlike the building A where the presence of concrete is dominating, both in its structural elements and in case of its finishing parts.

However, it should be stressed that this method was developed for the Dutch market and adjusted to Dutch building practice. Therefore, some materials and building principles which are common in case of Serbia, but nor in case of the Netherlands and vice versa, were not evaluated properly. This indicates need for certain adjustment of this method to our, local needs.

Conducted evaluation according to the HBM method showed that certain of the applied building materials, in cases of both model buildings, were unacceptable from the point of view of their impact to the health of the users. Therefore they are not recommended for such use. Materials from this group are: a) vinyl-asbestos plates, due to the content of vinyl and potentially hazardous asbestos fibers. They have toxic impact on the health of the users during usage and demolition. b) mineral wool, due to the content of mineral fibers which could be harmful if inhaled. Other applied building materials fulfilled to the great extent the set criteria and therefore could be considered as absolutely harmless for the users' health.

However, there is one potentially hazardous thing for the health of the users that this method did not take into account. It is the fact that reinforced concrete together with distribution of different installation systems, especially that of electrical installation, creates an effect of a so called "Faraday's cage", meaning that there is a disturbance of electromagnetic field in such spaces. Having this in mind, advantage is given to the model building $\mathrm{B}$, since its building technology required the minimum use of reinforced concrete (for the purpose of seismic requirements and monolithization of connections between structural elements), while in the case of the other building A, reinforced concrete is present both for creation of structural elements, as well as for partition elements and cladding.

When compared with EU recommendations for sustainable construction, obtained results show that basic requirements regarding the need to apply ecologically friendly and durable materials were fulfilled to the great extent. Fulfillment of the set criteria regarding the use of local materials, design rationalization and decrease of the need for materials (especially when the use of prefabricated and semi-prefabricated ceramic and concrete products is concerned, since these are local and long-lasting materials) was present in case of both model buildings. Requirement for the application of materials from renewable resources, those that are considered ecologically friendly and healthy, avoiding the use of dangerous materials and substances was only partially fulfilled, mostly due to the wide 
application of reinforced concrete and other cement-based materials, as well as materials like PVC and asbestos which have harmful impact on environment and users. The greatest difference from the EU recommendations could be recognized in the domain of recycled materials application, designing that enables re-use (dismantling of buildings and their components), designing that enables recycling. In spite of the fact that both buildings represent examples of prefabricated or semi-prefabricated building technology, applied system of connections between components practically precludes further recycling of buildings and their components. Therefore, neither re-use of components, nor recycling of individual materials is possible.

\section{CONCLUSION}

Generally speaking, research results point out that, in case of chosen building models, applied materials had more or less satisfactory environmental properties. However, there are certain particularities that this research revealed.

On one hand, the majority of building materials that were applied on investigated building models had fulfilled set requirements regarding their health impact and showed good results in this domain. On the other hand, great number of applied materials, in both cases, expressed very poor results when other potential environmental impacts, local and global were concerned. This fact points out possible difficulties regarding total environmental potentials of a building material, since, as the conducted research has shown, the primary interest of users is satisfied, but it does not include questions of a environment status, nor environmental impacts that materials could have, which may have long-term and hardly predictable consequences. However, nowadays environmental properties of building materials, e.g. their choice and potential impact become very important for the process of creation of sustainable urban environment.

As it was demonstrated, the question of environmental profile of a building material brings with it the entire hierarchy of facts and correlations which emphasize the complexity, not only of the problem, but also of measures and procedures that should be considered in order to obtain an adequate answer. Considering the long-term consequences that building construction could have on a global level, simplified and partial observation of such a complex matter of environmental friendliness can not offer a complete picture of the problem.

It is obvious that Serbian society is just about to face the necessity of registering and evaluating the potentially harmful impacts that building materials could have on environment as a result of activities in a building sector of its economy. In the future, this should lead towards changes in attitude regarding the construction technology of our buildings, but also regarding more thorough choice of building materials that are used for this purpose. It could be also concluded that, in case of Serbian or any particular society, critical evaluation of ecological profile of building materials should take into consideration its particularities. This requires certain modifications of so far known evaluation tools and their adjustment to the local needs. Building trends, legislation and norms, particularities of local building industry and local climate are some of the parameters which should be considered during the required adjustment of tools. 
Finally, although this research offers certain idea about the situation in our building industry regarding ecological characteristics of applied building materials and products, it should be considered just as a starting point of a much wider research. One of the future steps should be transfer of obtained results from the level of building material to the building level, which represents a totality in which impacts from each of its integral parts are gathered and superposed. This should be one of the primary problems in the future that requires our maximal attention and awareness.

\section{REFERENCES}

1. Anink, D., Boonstra, C., Mak, J.: Handbook of Sustainable Building, An Environmental Preference Method for Selection of Materials for Use in Construction and Refurbishment, James\&James, London, 2001.

2. Berge, B.: Ecology of building materials, Architectural Press, Oxford, 2000.

3. Curwell, S., Fox, B., Greenberg, M., March, C. :Hazardous Building Materials - A Guide to the Selection of Environmentally Responsible Alternatives, Spon Press, Taylor\&Francis group, London, 2002.

4. Krnjetin, Slobodan: Graditeljstvo i zaštita životne sredine, Prometej, Novi Sad, 2001.

5. Međunarodni standard ISO 14040:1998(E): Upravljanje zaštitom životne sredine-ocenjivanje životnog ciklusa-principi i okvir, 1998.

6. Međunarodni standard ISO 14011:1998: Upravljanje zaštitom životne sredine-specifikacija sa uputstvom za primenu, 1998.

7. Međunarodno uputstvo ISO guide 64:1997: Uputstvo za uključivanje aspekata životne sredine u standarde za proizvode, 1997.

8. Mihajlović-Ristivojević, M., Radivojević, A.: Istraživanje materijala za energetsku racionalizaciju objekata na principima ocene životnog ciklusa materijala, Energetska optimizacija zgrada u kontekstu održive arhitekture, deo 2, Arhitektonski fakultet Univerziteta u Beogradu, Beograd, 2005, pp. 65-86.

9. Mihajlović-Ristivojević, M.: Odnos trajnosti i kvaliteta građevinskih materijala u svetlosti novih ekoloških shvatanja, Zbornik 24. Konferencije JUSK, Beograd, 1997, pp. 183-188.

10. Nenadović, A., Nenadović, M.: Građevinski materijali i proizvodi u kontekstu održivog razvoja, Principi održivog razvoja-problemi redefinisanja i metodologija unapređenja, Arhitektonski fakultet Univerziteta u Beogradu, Beograd, 2004, pp. 237-255.

11. Roaf, S.: Ecohouse 2, Architectural Press, Oxford, 2003.

12. Zakon o zaštiti životne sredine RS, Sl. glasnik R.S., br. 135/04

13. Zakon o integrisanom sprečavanju i kontroli zagađivanja životne sredine, Sl. glasnik R.S, br. 135/04

14. http://erg.ucd.ie/ec2000.html, May 2006.

15. http://enviroinfo2004.org/cdrom/datas/deakins.htm, January 2006.

16. http://www.ecocityprojects.net, May 2006

\section{PROCENA EKOLOŠKE ISPRAVNOSTI GRAĐEVINSKIH MATERIJALA - PRIMER DVA VIŠESPRATNA STAMBENA OBJEKTA U BEOGRADU}

\section{Ana Radivojević, Miloš Nedić}

Ekološka ispravnost građevinskih materijala postaje značajan faktor u savremenom konceptu projektovanja i građenja i preduslov za stvaranje održivih objekata, odnosno, održive arhitekture. Kako je u našim uslovima pomenuti koncept tek u povoju, bilo bi interesantno da se ustanovi kakav je odgovor do sada pružila domaća graditeljska praksa u tom kontekstu. Stoga su odabrani reprezentativni objekti sa prostora Beograda. na kojima je, korišćenjem već razvijenih metoda $i$ alata za procenu ekološke ispravnosti objekata, izvršena odgovarajuća ekološka procena. Rezultati ovog istraživanja su prikazani u radu. 